\title{
Transfer of Computer Knowledge and Skills to the Workplace: The Perspective of Primary School Heads
}

\author{
Philip Bulawa \\ Department of Primary Education, Faculty of Education, University of Botswana \\ Private Bag 0022, Gaborone, Botswana
}

Tel: 267-355-5095Ｅ-mail: bulawap@mopipi.ub.bw

Received: Oct. 6, 2016 Accepted: Nov. 4, 2016 Published: November 4, 2016

doi:10.5296/jse.v6i4.9992 URL: http://dx.doi.org/10.5296/jse.v6i4.9992

\begin{abstract}
The use of computer technology in schools has become a topical subject of enquiry among researchers globally. As in other countries, the government of Botswana has come up with policy on the use of computer technology in public schools in its effort to improve teaching and learning. For this initiative to be achieved, higher education institutions in the country are expected to provide knowledge and skills to school management teams and members of their teaching staff on Information and Communication Technologies (ICT). This descriptive and qualitative study sought to find out whether primary school heads are using the computer knowledge and skills they acquired during in-service training at the University of Botswana in their schools. Using purposive sampling, 22 participants out of 26 who had volunteered to participate in the study responded to the questionnaire about the use of computers by school heads in primary schools. The result of the study shows that while school heads are willing to use computers in their schools, they have encountered some challenges, many of which are external and therefore, beyond their control. Further revealed is that there are a few school heads that do not see the use of computers as a priority, in spite of the knowledge and skills they possess. The study recommends further research to find out from regional officers the intervention measures that may be put in place to enable school heads to effectively use computer technology in primary schools.
\end{abstract}

Keywords: Higher Education Institutions, ICT, School Heads, Primary Education 


\section{Contribution to Existing Knowledge}

This study has added to the body of knowledge available regarding transfer of learning to the work place, especially knowledge and skills transferred from higher education institutions to primary schools in less developed countries. The study has opened a window of opportunity for our understanding of the school heads' experience of applying ICT in primary schools in Botswana.

\section{Background}

Developments in Information and Communication Technologies (ICTs) have had an impact on all sectors of society, including the education sector, with application of ICTs in the form of e-learning already changing teaching and learning processes in higher education (Sife, Lwoga, \& Sanga, 2007). In Botswana the government has been sponsoring in-service school management students, including primary school heads, the focus of this study, to study at the University of Botswana to upgrade their qualifications to degree level in educational management. Students on this programme register for different core management courses, and one such course is "Computer Applications in Primary Schools" offered in the Department of Primary Education (University of Botswana, 2014/15, p. 65). The aim of the course is to prepare them for using computers in primary schools (Bose, 2004).

This computer course responds to a recommendation by the Revised National Policy on Education (RNPE) of 1994 and Vision 2016 to have information technology introduced in schools to make Botswana an information society (Republic of Botswana, 1994a; Republic of Botswana, 1994b). Furthermore is the need for citizens of Botswana "to use and apply the potential of computer equipment in their daily life" (Republic of Botswana, 1994b, p. 35). It is also in line with the New Partnership for Africa's Development's (NEPAD's) e-Schools programme which emphasises the important role of teacher training in ensuring among other things, that a majority of the people on the African continent "have skills that are required to function in the knowledge economy" (Unwin, 2005, p. 117).

The role of school heads in the introduction of computers in schools is pivotal in ensuring the integration and infusion of computer skills "into the core and optional subjects at the upper primary level," thus, concerted effort must be made to offer computer training in teacher training institutions (Bose, 2004, p, 404). A study by Batane (2004) has revealed that, where computers have been introduced in some junior secondary schools in Botswana, most teachers lacked computer knowledge and skill because computers were not offered during their pre-service training. In this study, a teacher who went through in-service computer training, appreciates the supportive role played by her school head whom she describes as doing everything in his power to get his teachers to participate in the training and in turn use computers in their respective subjects. In the teacher's view, through the involvement of the school head, the school has been able to get more teachers participate than if he was not part of the job.

Consequently, one can conclude that it is in the best interest of school heads as instructional leaders and drivers of school reforms (Republic of Botswana, 1994) to register for the 
computer course offered at the university. The knowledge and skills acquired during training would not only benefit them personally and professionally, but also that upon completion of their study they should be able to cascade what they learnt down to their teachers and students. In this study, it was important that the views of primary school heads be sought since studies that have been conducted on computer technology in education, have mainly focused on secondary schools in Botswana (Batane, 2004; Totolo, 2011). There have not been any empirical studies conducted to find out about perceptions and experiences of primary school users regarding adoption of computer technology. The aim of this research was therefore, to find out the likelihood of transfer of computer technology to the workplace in Botswana, specifically among primary school heads.

\section{Conceptual Framework}

The conceptual framework adopted in this study is that of transfer of learning and knowledge which is becoming increasingly important in organisations (Barnett \& Ceci, 2002; Argote, Ingram, Levine, \& Moreland, 2000). This has been defined in terms of "the ability to apply knowledge gained in one situation to bear in another similar situation" (Lauder, Reynolds, \& Angus, 1999, p. 480). The concept is not new as its significance for both everyday functioning and theory has been documented for more than a century. However, there has been little agreement amongst scholars regarding the nature of transfer, the extent to which such transfer occurs, as well as the nature of its underlying mechanisms. Some questions have been posed regarding what is really known about transfer of knowledge, how to ensure that knowledge is well learnt, "that is ways in which teaching can be optimally tailored to promote transfer" (Barnett \& Ceci, 2002, p. 612).

Notwithstanding this intense debate with no greater consensus amongst scholars about the issue of transferability of learned skills, the literature read shows that this has not only been prevalent (Bridges, 1993; Barnett \& Ceci, 2002), but that there has been some evidence of successful transfer (Argote, Ingram, Levine, \& Moreland, 2000). Argote, Ingram, Levine, and Moreland (2000) maintain that "organisations that are able to transfer knowledge effectively from one unit to another are more productive and more likely to survive than those that are less adept at knowledge transfer" (p. 1).

According to Bridges (1993), "the term transferable skills, tends to be preferred when people are talking about the application of skills across different social contexts" (p. 45). He maintains that, "more central to a properly educative endeavour is the identification of what is involved in the transferring skills or what it is that enables someone with some knowledge, learning, understanding or skill gained in one cognitive domain and/or social context to adapt, modify or extend in such a way as to be able to apply it in another" (p. 50). Lauder, Reynolds and Angus (1999) argue that intellectual skills that have been gained during a course of study can be transferred to another situation.

Research shows that there are skills which can be deployed with little or no adaptation in a variety of social settings. A typical example could be word processing which might involve the same skills whether one was doing it in a university, or an office pool (Bridges, 1993). In a study about teachers' use of information and communications technology, Mumtaz (2000) 
reveals that the use of computers with students has been found not only limited to gaining computer competence, but also "extended to involvement in cognitively challenging tasks where computers are tools to promote communicating, thinking, producing, and presenting ideas" (p. 324-325).

Studies further reflect that the extent to which transferability may take place depends on several factors, which include, motivation to transfer and individual attitudes. Motivation to transfer has been defined as the utilisation of the skills and knowledge that have been learned in a training atmosphere to the real world situation. While individual attitudes that a trainee brings may not be directly related to the training programme, they are however, expected to influence both motivation to learn and motivation to transfer. This therefore, suggests that those individuals who enjoy learning new things are bound to be more motivated to attend and participate in training and practise what they would have learnt (Seyler, Holton III, Bates, Burnett \& Carvalho, 1998).

Drawing on past studies regarding teachers' use of technology, Windschitl and Sahl (2002) reveal that "contextual factors such as the characteristics of staff development experiences, access to technology, availability of support, and opportunity to interact with colleagues contribute to the behaviour of individuals" (p. 166). Similarly, Seyler, Holton III, Bates, Burnett and Carvalho (1998) consider organisational climate as "the single most important factor affecting efforts to apply new knowledge in the actual job setting" (p. 3). Argote, Ingram, Levine, and Moreland (2000) emphasise the significance of understanding knowledge transfer in organizations, which would mean having to move beyond understanding how an individual applies knowledge from one context to another to understanding how such larger collectivities as groups, departments, and divisions achieve this transfer.

Against this background, this study is grounded on the conceptual framework of transfer of learning, knowledge and skills, and seeks to investigate whether primary school heads in Botswana who have completed a B. Ed. (Educational Management) degree, have been able to "utilise and integrate" (Fisher, 2000, p. 109) computer knowledge and skills they learnt at the University of Botswana "into their working lives" (Windschitl \& Sahl, 2002, p. 166) and in this case the school context (Galanouli, Murphy, \& Gardner, 2004). The study focuses on "the nature of the skill to be transferred" (Barnett \& Ceci, 2002, p. 614), and if school heads show the capacity to apply something they have learnt in one context to another, that would demonstrate that they have mastered a transferable skill (Bridges, 1993). Mumtaz (2000) emphasises the significance of adequate and careful training in order for teachers to be aware of the different uses and possible benefits of Information and Communication Technology (ICT).

\section{Literature Review}

Over the years, the major thrust in the world has been the search for ways in which teachers could be convinced that ICT should be a fundamental part of their teaching strategy. In the process a range of approaches have been tried that include the dissemination of good practice and the investment in infrastructure and equipment. The key strategy has been the training 
programmes designed to raise skill levels and foster positive attitudes to computers among teachers (Galanouli, Murphy, \& Gardner). Education authorities have invested heavily on the introduction of computers in schools and training of teaching staff in their use (Sadik, 2006). In some cases this has included "the technology courses offered and the days set aside for instructing teachers and administrators how to use the hardware and software," as well as on-site technical support provided by among others, designated teachers (Cuban, Kirkpatrick \& Peck, 2001, p. 819).

The significance of using computer technology in education as noted in the literature emphasises that successful models of ICT professional for teachers should address different concerns which include the provision of sufficient time, good technical and social support, and good equipment and resources. A model of delivery that is flexible and reflective of the individual needs and levels of ICT competence of those involved is recommended (Galanouli, Murphy, \& Gardner, 2004). Galanouli, Murphy, and Gardner (2004) indicate that their study about ICT training for teachers revealed that where it was successful, it not only increased teachers' confidence to use ICT, but also resulted in increased frequency of ICT use in their teaching. As in other educational institutions globally, higher education institutions in Africa have "seized on technology as a way to better prepare the workforce for a competitive economy" (Sadik, 2006, p. 87). As pointed out by Modimogale and Kroeze (2011), ICT is regarded as the foundation upon which the knowledge economy is based.

An overview of the literature in general, as well as the focus on the literature specifically on education in Africa provides evidence of the initiatives that are being taken in higher education institutions "to integrate information and communication technologies (ICTs) to improve their curricula" (Lwoga, 2012, p. 91). ICT has among other things, increased opportunities for the rapid information exchange that facilitates teaching, research, and lifelong learning, and also led to the globalisation of higher education. In most education settings, ICT is regarded as a potential "solution for the problem of having to do more with less, providing access to increasingly diverse demography of students and faculty and improving both the quality and quantity of educational content" (Adam, 2003, p. 197).

Unwin (2005) points to numerous international and national schemes in Africa over the last decade that have been designed to introduce ICT into schools and that most of these have been introduced with the best of intentions. Notable initiatives that have indeed gone beyond merely introducing computers into schools, but further given teachers some training in how to use Microsoft Office packages on them, include the Connectivity for Educator Development programme in Uganda, and Schools OnLine's programmes in Senegal and Tanzania.

In Botswana, there have also been some initiatives to introduce ICT especially in secondary schools (Totolo, 2011). The government's commitment to the use of ICT in education is clearly reflected in Vision 2016, a national development strategy which stresses the need for Botswana to have entered the information age on an equal footing with other nations by 2016, and that schools at all levels will have access to state-of-art ICT to support the learning process (Mutula \& Mutula, 2007; Republic of Botswana, 1994b). In response to this national strategy, the University of Botswana started the process of integrating e-learning strategy in 
the teaching and learning process (Mutula, 2002). This was in recognition of the need to invest in human capital, research and development, critical factors in preparing citizens to participate in the digital age (Mutula \& Van Brakel, 2007). A study conducted by Unwin (2005) about the use of ICT in education in Africa also alluded to "possible framework for the successful implementation of teacher training programmes that make advantageous use of appropriate ICTs" (p. 113). Further emphasised is the importance of teachers first to be provided with basic ICT skills.

The provision of ICT resources to the education sector in Zimbabwe has also been growing at a rapid pace since 2002. It was however, not until 2005 that the Zimbabwean government developed a national ICT policy that made significant references to the promotion of ICTs in education including their pedagogical use in educational institutions. With this significant development, the office of the President also embarked on a campaign that provided most schools, including those in the remote areas of Zimbabwe and universities with computers that enabled them to utilise ICTs in the teaching and learning process (Musarurwa, 2011). Another African country Egypt, introduced computers into schools to improve the quality of the education system. The introduction of technology was seen as "developing in thinking, deducing, and arranging information; improving the performance of students; and increasing the capacities of information exchange" (Sadik, 2006, p. 87). Cuban, Kirkpatrick and Peck (2001) make mention of the use of computers for among other things, "word processing, doing internet searches, and completing projects" (p. 822). Therefore, as one of the Ministry of Education's many projects in Egypt, the aim was to equip every school with the latest desktop technology, with many primary schools and all preparatory and secondary schools provided with multimedia rooms and computer labs (Sadik, 2006).

While such ICT initiatives are a welcome development in education, especially in Africa, challenges to implementation have been reported in the literature, with African higher education institutions "at a stage where they are striving to improve their information and communication technologies (ICTs) infrastructure, content, and skills; making resources available to meet the growing needs of students and faculty; and responding to the pressure for effect" (Adam, 2003, p. 195). Unwin's (2005) observation based on World Link's evaluation of Teacher Training Programmes in both Latin America and Africa, shows that the use of computer technology faces some challenges, that include teachers' concern about "the lack of computers, inadequate hardware/software, unreliable Internet access, and scarcity of time" (p. 116) as major barriers that have kept them from using computers in their teaching. Further highlighted as lacking in educational institutions in Africa are educational software installed on computers and the servers with which they are networked.

A study carried out in some universities in Tanzania also points to poor infrastructure which includes low internet bandwidth, lack of technical support and high cost of internet connectivity as some of the barriers that have constrained their e-learning activities (Lwoga, 2012). Thus, some teachers in selected African countries have expressed the need to be provided with more technical support to enable them to integrate ICT into the curriculum (Unwin, 2005). In Kenya, Tanzania and Zambia, a study by Kessy, Kaemba, and Gachoka (2006) has similarly revealed among other things, that the extent to which ICT may be used 
in education could be affected by several factors, including the cost of "the purchase of ICT media, hardware and software; the setting up of appropriate telecommunication networks; maintenance and repair of facilities when necessary. These costs are in most cases exorbitant and cannot be provided for by most African countries" (p. 1). Other factors also mentioned as potential barrier to the use of ICT in Africa include cultural attitudes and ignorance. There is also concern by Unwin (2005) that where computer laboratories exist in educational institutions, often they are underutilised. He describes this as wasteful, since new technologies are likely to have a positive effect on learning attainment and educational practices if they are managed and utilised appropriately. In addition, most of educational computers are mainly used to teach keyboard skills or for office type packages amongst them, word processing, presentation software and spreadsheets, tools which have very little to do with pedagogic practices.

Many ICT initiatives in Africa have been externally funded especially by western donor agencies, and this has had its own implications. For instance in Zimbabwe, the fact that it was an external partner who identified the gap that existed within the higher education sector, particularly within teacher education, and that there was a need to provide both ICT resources and skills has limitations, which include sustainability and replication of such donor funded projects. Another challenge is whether ownership of change could be guaranteed in such a scenario where an external partner initiates change, a situation that also has the potential to threaten sustainability of external driven ICT initiatives. Evidence in the literature shows that in many instances, external funded programmes end with the expiry of external partnership (Musarurwa, 2011).

\section{Purpose of the Study}

This study sought to investigate primary school heads' perceptions regarding an ICT course offered to them at the University of Botswana, and the extent to which research participants have been able to transfer the computer knowledge and skills they acquired to the school context.

\section{Research Questions}

This study is guided by the following research questions;

1. What are the participants' perceptions and experiences about the computer course they did at the University of Botswana?

2. In what way have participants utilised knowledge and skills they learnt during training?

3. What are the participants' perceptions regarding the challenges they have encountered trying to transfer knowledge and skills to the workplace?

\section{Research Methods}

The research participants were school heads who had completed a B. Ed (Educational Management) degree who were attending a primary school heads conference held in Gaborone, the capital city of Botswana. They were selected through a purposive sampling 
strategy designed to enhance understandings of their perceptions and experiences (Devers \& Frankel, 2000) about the use of computer knowledge and skills in primary schools (Bose, 2004). Purposive sampling techniques "are primarily used in qualitative (QUAL) studies and may be defined as selecting units (e.g., individuals, groups of individuals, institutions) based on specific purposes associated with answering a research study's questions" (Teddlie, 2007, p. 77).

The study adopted a qualitative approach to assess the perceptions and experiences of primary school heads, and used a structured questionnaire to collect the data. This approach was more appropriate for this study because data collection was carried out during a national primary school heads conference where school heads who completed the computer course at the University of Botswana also attended. However, one of the disadvantages of using questionnaires is that it is rare that all of them will be returned (Patton, 2002). Evidence of this was that a purposive sample of 22 participants responded to the questionnaire out of a possible twenty-six (26). The focus of the study was the participants as individuals to answer three research questions about their perceptions and expectations regarding the use of computer knowledge and skills in primary schools in Botswana. To ensure anonymity, it was explained to the school heads that the data to be collected would remain confidential and not be shared with anybody, and that the identity of their schools would also not be revealed (Hameiri \& Nir, 2016).

These participants are part of a selected group of graduate primary school heads who had undergone a full-time in-service programme sponsored by the government of Botswana to upgrade their academic qualifications to degree level. This is a Bachelor of Education (Educational Management) programme which was introduced in 2005 and is offered at the University of Botswana. Therefore, all the school heads in this study hold the same qualifications, and it is assumed that, they all have equal chances of making the most of the computer knowledge and skills in any of the primary schools in Botswana. School heads were chosen for this study because of the pivotal role they play in schools, which entails having to take responsibility for in-service training of teachers in their schools (Republic of Botswana, 1994a) and to be in the forefront of the implementation of change in schools (Bulawa, 2013).

As leaders in their schools, the knowledge and skills they acquired during training at the university stand to increase their self-confidence with technology use, and give them a desire to transform teachers' perspectives of their profession by using ICT (Galanouli, Murphy, \& Gardner, 2004). The transformation of teachers in this respect is a responsibility of school heads, as clearly stated in the Revised National Policy on Education that, their position as instructional leaders, compels them to take responsibility for in-service training of their teachers (Republic of Botswana, 1994a) to ensure that they embrace the use of computer technology (Totolo, 2011).

In can be concluded that, the knowledge and skills acquired during training, would then capacitate school heads to use a wide range of approaches to the professional development of their teachers on computer technology. Drawing on Watson (2001), Galanouli, Murphy, and 
Gardner (2004) recommend four models namely, "the home-grown expert approach, the comfortable shoes approach, the let them struggle approach and the killer application approach" (p. 65), that can be used to provide ICT professional development. For instance, using the home-grown expert approach, would mean that the school head is a professional development tutor "who has gone through the process and is viewed by the teachers as having come from the trenches, making them more open to the training provided" (p. 65). The second approach referred to as comfortable shoes, would involve the trained school head as the tutor having to demonstrate the techniques and then closely monitor and support the teachers working by themselves. It is recommended that some of these approaches may be combined to become the answer to the problem of providing successful ICT professional development.

\section{Findings and Discussion}

The research findings presented in this study, focus on the perceptions and experiences that primary school heads have had about the computer course they did at the University of Botswana, and transfer to the workplace computer knowledge and skills they acquired during training. With respect to ICT in education in Africa, Unwin (2005) alludes to a framework for the successful implementation of teacher training programmes that would make advantageous use of appropriate ICTs. The findings address the research questions that ask: i) What are the participants' perceptions and experiences about the computer course they did at the University of Botswana? ii) In what way have participants utilised knowledge and skills they learnt during training? and, iii) What are the participants' perceptions regarding the challenges they have encountered trying to transfer knowledge and skills to the workplace? The findings reported here reveal a range of participants' perspectives. These are school heads' learning experience of the computer course at the University; use of computer knowledge and skills by school heads in their work place; constraints to the use of computer technology by school heads; ways in which the use of computers has improved school heads' work; school heads' suggestions about how the use of computers can be improved in schools; and the nature of support required by school heads for effective use of computers.

\subsection{School heads' learning experience of the computer course at the University}

As indicated in the literature on ICT, the University of Botswana has integrated e-learning strategy in the teaching and learning process (Mutula, 2002), and the findings show the this initiative has benefitted participants in this study. Most of them reveal that prior to their enrolment for this course, they either did not have or did have minimal basic computer knowledge and skills. The findings further show that with the help of their lecturers, most of them $(62 \%)$ found it easy to learn basic computer skills, with a minority but significant number of participants $(36 \%)$, revealing that while they initially found it difficult to learn computer skills, they gradually improved with time. The remaining two percent do not indicate their view. On whether they were allowed to learn computer at their own pace, 50\% of participants are in agreement that this was allowed, while $49 \%$ point out that they did not think that they were given enough time to learn at their own pace. This category of participants argues that their schedules were congested with too many other courses to be 
able to find sufficient time for their computer course. The remaining one percent does not express any viewpoint.

A majority $(75 \%)$ of participants point out that, computers at the university were readily accessible to students at different times of the day, while $25 \%$ of them express concern that computers were not accessible. Participants have also been asked if they received any support from their lecturers outside normal lecture time. Most participants are content with the assistance provided by their lecturers outside the official time allocated for lectures, and are of the view that this was what mainly motivated them to develop interest in the course and therefore learn more. Only two participants deny that such assistance was ever provided.

Lecturers are further commended by the majority of participants for showing positive concern about their students' learning progress, while only one participant is of the view that lecturers did not show much concern. A minority but quite a considerable $20 \%$ of participants fail to state their position. Although participants differ on lecturers' concern about their progress, they unanimously agree that the teaching methods offered in their computer course were appropriate for their learning styles. Generally, they reveal that it was because of these user friendly teaching methods that they developed interest in the learning of computers. This shows that as students, their desire to learn was influenced by among other things, internal work motivation, and organisational commitment (Seyler, Holton III, Reid, Burnett, \& Carvalho, 1998). Most participants point out that they have successfully completed their computer course, and that their expectation of the computer course has been met.

\subsection{Use of computer knowledge and skills by school heads in the work place}

The findings show that the majority of participants have computers or laptops in their offices, which are either owned by the school or are their own personal property. However, there are some participants who are concerned that while they have office computers, these have not been working for a long time. In their view it has taken a long time to either get them repaired or replaced. Those with functional computers highlight different ways in which they use them. Those commonly mentioned by most participants include; recording and storing of information/record keeping; compilation of reports; typing of students' assignments and tests; access to or use for email as reflected in Table 1 below.

Table 1. Specific use of computers by school heads

\begin{tabular}{|l|c|c|}
\hline Specific use of computers & $\begin{array}{c}\text { Number of } \\
\text { responses }\end{array}$ & $\begin{array}{c}\text { Percentage of total } \\
\text { responses }\end{array}$ \\
\hline $\begin{array}{l}\text { Recording and storing of information/record } \\
\text { keeping }\end{array}$ & 16 & $72 \%$ \\
\hline Compilation of reports & 12 & $55 \%$ \\
\hline Typing of students' assignments and tests & 9 & $41 \%$ \\
\hline Access to email/Use for email & 6 & $27 \%$ \\
\hline
\end{tabular}

These expressed views by participants represent diverse use of computers in the work place, with one school head indicating that he uses the computer for "disseminating information to different stakeholders i.e. mail, and for storing and updating teachers' records, reports and 
others." A school head in another school lists a range of usages of the computer such as, "To write memos. To record and store information such as profile of pupils and staff," while another one reveals: "I use the computer in my office to type information, certificates of appreciation and keeping records for the whole school for easy reference".

Furthermore, in another school, the school head states: "I have a computer in my office which I use to improve my work. It helps me to reduce hard files, instead I use soft copy. I've bought a modem, so I access the internet to find information to use in improving the school". Other notable comments by participants regarding the use of computers include: "I use it for capturing school data." "It helps me in responding to correspondence and analysing students' academic results." "I rely on my computer for workshop presentations using powerpoint." "I use my computer for making learning/teaching aids." "Setting tests and examinations is quicker using a computer." "I personally write for myself and have confidentiality of my supervisees." Most of the comments are in accord with some reflections in the literature on educational computer technology that reveal that computer users in some schools have found computers useful in their job (Totolo, 2011). In Africa generally, studies also show the benefits of some educational computer programmes (Unwin, 2005).

\subsection{Constraints to the use of computer technology by school heads}

Many participants indicate that while they have computers in their offices, they have not fully utilised them mainly due to constraints beyond their control. The major challenge they have cited is that in most cases the school head's computer is the only one available for use by the entire staff, and that with so many people sharing the same computer, school heads find little time to effectively apply the knowledge and skills they learnt at the University of Botswana. It has also emerged in the findings that the same challenge of insufficient computers in schools has become an impediment to school heads efforts to share their knowledge and skills with students. As pointed out by Lauder, Reynolds, and Angus (1999), unavailability of computers in schools would certainly be a major constraint to the school heads' ability to apply knowledge gained in one situation to bear in another similar context. Participants are further concerned that a single computer which is continuously used by all members of staff, is exposed to regular attack by virus. Regular damage due to lack of care for the computer when it changes many hands, has also been reported.

What further emerges in the findings is that there are several schools with a number of computers, but are mainly unusable due to lack of software and technical assistance. This is what one of the participants has pointed out about a shared computer in her school. "The computer since it is shared is continuously attacked by virus and takes time for it to be attended to." On why computers are not being used to their full potential in schools, Mueller, Wood, Willoughby, Ross and Specht (2008) also point to equipment based issues such as limited access, technical problems and malfunctions as major barriers. Such factors as lack of computers, inadequate hardware/software, and unreliable Internet access are further reported in the literature as factors that have adversely affected the use of computer technology in schools in Africa (Unwin, 2005; Kessy, Kaemba, \& Gachoka, 2006); Musarurwa, 2011). 
Table 2 below shows some most constraints to the use of computer technology by school heads.

Table 2. Constraints to use of computers technology by school heads

\begin{tabular}{|l|c|c|}
\hline $\begin{array}{l}\text { Constraints to use of computers } \\
\text { technology }\end{array}$ & $\begin{array}{c}\text { Number of } \\
\text { responses }\end{array}$ & $\begin{array}{c}\text { Percentage of total } \\
\text { responses }\end{array}$ \\
\hline $\begin{array}{l}\text { Only one computer available for entire } \\
\text { staff }\end{array}$ & 20 & $91 \%$ \\
\hline Lack software & 19 & $86 \%$ \\
\hline Lack of technical assistance & 18 & $82 \%$ \\
\hline Computer malfunctions & 16 & $72 \%$ \\
\hline
\end{tabular}

Only two participants have disclosed that they do not see the use of computers as their major responsibility as school heads. One of these two participants points out: "I have not been personally using the computer in my office. But I'm computer literate, so using a computer will not be a problem". Similarly another one explains; "I can use a computer, but as a school head I have too many administrative duties to do to be able to spend time on the computer. When I have work to be typed, the secretary or some members of my teaching staff do it for me." The sentiments expressed by these participants could be attributed to individual attitudes on the part of some school heads, and attitudes have the potential to influence both motivation to learn and motivation to transfer (Seyler, Holton III, Reid, Burnett, \& Carvalho, 1998) computer knowledge and skills to the workplace, or as Windschitl and Sahl (2002) put it, to integrate these into their working lives.

\subsection{Ways in which the use of computers has improved school heads' work}

The participants are unanimous about some improvements to the quality of their work in schools due to the use of computers. In cases where ICT training has been reported as successful in education, it increased practitioners' confidence to use ICT (Galanouli, Murphy, \& Gardner, 2004). Such investment in human capital is regarded as one of the critical factors in preparing citizens to participate in the digital age (Mutula \& Van Brakel, 2007). Even a minority participants who have indicated that they do not have any functional computers in their schools, acknowledge the potential value addition of computers to their work. Participants highlight several common areas in which the quality of their work has been enhanced due to the use of computers in their schools. "There is fast dissemination of information. There is computer storage of information and we are moving away from manual filing. There is also neatness and easy sharing of data."

Another school head who appreciate the benefits of using the computer has listed the following: "Faster in meeting deadlines and set standards. Improved reporting. Neatness. Research and improved communication through e-mail and social networks". Furthermore are similar comments such as; "It's helpful in meeting deadlines, neatness and better reporting. It has improved service to clients". In addition, are the following sentiments by another school head. "It enables work to be completed faster, and efficiently. It improves 
content delivery through research. It keeps me abreast of up to date programmes and policies".

\subsection{Participants' suggestions on improvement in the use of computers in schools}

The participants are unanimous regarding improvement in the use of computers in schools. Several suggestions are made regarding steps that could be taken to improve the use of computers in schools. All school heads express the view that it is government's responsibility to provide schools with sufficient computers, with one school head suggesting: "The government must provide more computers with software and internet connection," while another one points out that, "the government needs to provide all primary schools with enough computers."

There have also been suggestions about the purchase of computers for the benefit of both students and teachers. For instance, one school head emphasises the need to "have more computers at least to be used by one class at a time." A similar comment is for the "provision of enough computers for staff members and students." A comparable study by Sadik (2006) shows that, the Ministry of Education in Egypt found it imperative to introduce computer technology into schools to improve the quality of the education system. The use of computers in schools was considered as a means through which, for example, improvement of the performance of students, and an increase in the capacities of information exchange could be achieved.

Some participants feel that it is not enough just to provide more computers but that there is need to provide other important services that would further enhance their use in schools. One school head argues that while more computers are required, it is equally important to "have specific timetable on computer awareness and research." She maintains that there is need to "provide manpower literacy in the use of computers to empower teachers and learners." Another school head states that the procurement of computers would enable teachers to "be carried on board to have computer basic skills and use them when teaching, and researching." In another school, the school head emphasises the need for "procurement of enough computer and provision of computer labs in primary schools" and for the government to "offer refresher and advanced courses" as well as "continuous in-service training in computer literacy."

There are some participants who strongly advocate for technical assistance to assist schools with computer related challenges as suggested by this school head. "IT officers be deployed to schools from regional office to help schools improve the use of computers." Another example is that of a school head who puts across her wish of "having ICT people who will teach both teachers and learners regularly to improve and enhance their skills." The emphasis by participants is on the need to provide more computers to enable school heads to share their knowledge and skills in different ways, including the training of teachers on basic ICT skills (Unwin, 2005).

The construction of "computer labs" and "internet connectivity" are also highlighted as developments that would enhance the use of computers in schools. One participant argues 
that it is urgent for the government to "purchase more computers and have them networked and improve internet connectivity which is currently slow." Another one has commented: "Connect schools to the internet to allow for the use of email."

\subsection{Specific support required by school heads}

Although participants' responses are wide-ranging about specific support they would require to be more effective in the use of computers, the majority feel that some form of training is a priority. Some examples of comments made by school heads include; "refresher and advanced courses should be offered." "Provide refresher courses on computing literacy especially website creation and other complex computing software and hardware management." "In-service training and advanced computer application programmes are important."

There are other responses such as, "Train teachers on computers;" "I would like to be further trained in advanced ICT skills such as SPSS;" and "I need more training on spreadsheet for me to be able to analyse school results." A school head in one school reveals: "I want to learn more on how to use the computer especially in graphic information as well as excel to feed the computer with the IIAA of reporting information." Similarly, in the literature, technology courses for teachers and administrators on how to use the hardware and software; and on-site technical support are also recommended (Cuban, Kirkpatrick \& Peck, 2001).

Other important support requirement for school heads include; technical assistance, provision of more computers, and internet connectivity. One school head points to the need "for the few computers supplied to be serviced regularly"; while another one maintains: "Provide technicians for schools." There is also emphasis on the need for schools "to be supplied with enough computers to be used by at least one class"; and "for all teachers to have computer skills." There are participants' comments regarding internet connectivity such as, "avail internet - this would enable networking, research and connectivity to the global world, that is, classroom connectivity," and "if the computer I have could be connected to internet this will be a great deal because technology is important."

\section{Conclusion and Recommendations}

This study has provided evidence to suggest that transfer of knowledge and skills from training to the workplace is important, and in organisations where such transfer is effective from one context to another, there is probability to be more achievable than in those that are less proficient at knowledge and skills transfer. However, both the literature and the findings show that while successful transfer of knowledge and skills may be achievable, there are limiting factors to the extent to which this could be realised. In this study, whereas school heads highly appreciate the value of the use of computer technology in their schools, they also site factors that have had a negative effect on their ability and capacity to transfer knowledge and skills from a training institution to the school context. The views of the school heads illustrate that where major barriers are prevalent, such transfer has proved difficult. In this case, a major constraint to the transfer of what they have learnt is lack of support from regional offices of the Ministry of Education and Skills Development. Most school heads' 
expectations of the ministry, is that it would provide them with the requisite support that include, the provision of computer laboratories, new computers, software and technical support, but that these have rarely been made available, resulting in failure to effectively utilise computers for the benefit of schools. Of further concern to school heads is that, in schools where there are some computers, the ministry has shown no or minimal interest to replace computers that have been rendered obsolete, or to repair malfunctioning ones.

The school heads have also reiterated that while they appreciate the computer course they did at the university, what they learnt during training were mainly basic computer knowledge and skills. Therefore, what in their view is lacking in primary schools, are continuous in-service training programmes to upgrade their own level of competence, which they consider critical to enable them to provide training to their staff and students beyond just basic computer knowledge and skills.

Recommendations drawn from these conclusions, include the need for the government of Botswana to give implementation of computer technology in primary education the priority it deserves. For instance, the literature shows that, when computer technology was introduced in junior secondary schools following the Revised National Policy on Education's recommendation (Batane, 2004), primary schools were left behind.

School heads have legitimate expectation to receive maximum support from the same ministry that has invested substantially on their study to do a computer course, among other core courses. It is therefore recommended that the Ministry of Education and Skills Development should liaise with the Department offering the computer course at the University of Botswana to get a clear picture of what the course entails. Such information stand to give the ministry a clear understanding of how best they can go about assisting school heads.

It would seem somehow, a number of primary schools have managed to secure some computers from private sources, and therefore it would be in the best interest of primary education if the ministry could support schools including maintenance of such computers. In the event that the ministry does not possess comprehensive and reliable information regarding what schools have or do not possess, then it may have to make a comprehensive survey of all the schools with computers and provide the necessary support informed by its findings.

Finally, it is further recommended that the ministry should give priority to continuous in-service training programmes to upgrade school heads' level of competence, to enable them to be more effective in their effort to assist their staff and students in the use of computer technology.

\section{References}

Adam, L. (2003). Information and Communication Technologies in Higher Education in Africa: Initiatives and Challenges. Journal of Higher Education in Africa, 1(1), 195-221. http://www.jstor.org/stable/24486119 
Argote, Ingram, Levine, \& Moreland (2000). Knowledge Transfer in Organisations: Learning from the Experience of Others. Organisational Behaviour and Human Decision Processes, 82(1), 1-8. http://dx.doi.org/10.1006/obhd.2000.2883

Barnett, S. M. \& Ceci, S. J. (2002). When and Where Do We Apply What We Learn? A Taxonomy for Far Transfer. Psychological Bulletin, 128(4), 612-637. http://dx.doi.org/10.1037/0033-2909.128.4.612

Batane, T. (2004). Inservice Teacher Training and Technology: A Case of Botswana. Journal of Technology and Teacher Education, 12(3), 387-410.

Bose, K. (2004). Computer Training Programme for Primary School Teachers in Teacher Training Institutions of the Southern Region of Botswana. Research in Post-Compulsory Education, 9(3), 4011-416. http://dx.doi.org/10.1080/13596740400200186

Bridges, D. (2006). Transferable skills: A philosophical perspective. Studies in higher Education, 18(1), 43-51. http://dx.doi.org/10.1080/03075079312331382448

Bulawa, P. (2013). Constraints to Senior Management's Capacity to Implement the Performance Management System in Senior Secondary Schools in Botswana. International Education Studies; 6(5), 56-67. http://dx.doi.org/10.5539/ies.v6n5p56

Cuban, L., Kirkpatrick, H., \& Peck, C. (2001). High Access and Low Use of Technologies in High School Classrooms: Explaining an Apparent paradox. American Educational Research Journal, 38(4), 813-834. http://dx.doi.org/10.3102/00028312038004813

Devers, K. J. \& Frankel, R. M. (2000). Study Design in Qualitative Research-2: Sampling and Data Collection Strategies. Education for Health, 13(2), 263-271. http://dx.doi.org/10.1080/13576280050074543

Fisher, M. (2000). Computer skills of initial teacher education students. Journal of Information Technology for teacher Education, 9(1), 109-123. http://dx.doi.org/10.1080/14759390000200075

Galanouli, D., Murphy, C., \& Gardner, J. (2004). Teachers' perceptions of the effectiveness of ICT competence training. Computers \& Education, 43, 63-79. http://dx.doi.org/10.1016/j.compedu.2003.12.005

Hameiri, L. \& Nir, A. (2016). Perceived uncertainty and organizational health in public schools. International Journal of Educational Management, 30(6), 771-790. http://dx.doi.org/10.1108/IJEM-05-2014-0060

Kessy, D., Kaemba, M. \& Gachoka, M. (2006). The reasons for under use of ICT in education: in the context of Kenya, Tanzania and Zambia. IEEE Computer Society, 1-5. http://dx.doi.org/10.1109/tedc.2006.31

Lauder, W., Reynolds, W., \& Angus, N. (1999). Transfer of knowledge and skills: some implications for nursing and nurse education. Nurse Education Today, 19, 480-487. http://dx.doi.org/10.1108/10650741211212359Lwoga, E. (2012). Making learning and Web 
2.0 technologies work for higher learning institutions in Africa. Campus-Wide Information Systems, 29(2), 90-107. http://dx.doi.org/10.1108/10650741211212359

Modimogale, L. \& Kroeze, J. H. (2011). The Role of ICT within Small and Medium Enterprises in Gauteng. Communications of the IBIM. http://dx.doi: 10.5171/2011. 369288

Mueller, J., Wood, E., Willoughby, T., Ross, C., \& Specht, J. (2008). Identifying discriminating variables between teachers who fully integrate computers and teachers with limited integration. Computers \& Education, 51, 1523-1537. http://dx.doi.org/10.1016/j.compedu.2008.02.003

Mumtaz, S. (2000). Factors Affecting Teachers' Use of Information and Communications Technology: a review of the literature. Journal of Information Technology for Teacher Education, 9(3), 319-342. http://dx.doi.org/10.1080/14759390000200096

Musarurwa, C. (2011). Teaching With and Learning Through ICTs in Zimbabwe's Teacher Education Colleges. US-China Education Review, 7, 952-959

Mutula, S. M. \& Mutula, D. L. (2007). ICT Integration in Botswana Secondary Schools: Digital Divide Factor and Implications for Information Literacy. Afr. J. Lib \& Inf. Sc. 17(2), 133-143.

Mutula, S. M. \& Van Brakel, P. (2007). ICT skills readiness for the emerging global digital economy among small business in developing countries: Case study of Botswana. Journal of Small Business and Enterprise Development, 11(3), 280-289. http://dx.doi.org/10.1108/07378830710754992

Patton, M. Q. (2002). Qualitative research \& evaluation methods. Thousand Oaks, CA: Sage Publications.

Republic of Botswana (1994a). The Revised National Policy on Education. Gaborone: Government Printer.

Republic of Botswana (1994b). Vision 2016: Towards Prosperity for All. Gaborone: Government Printer.

Sadik, A. (2006). Factors Influencing Teachers' Attitudes Toward Personal Use and School Use of Computers: New Evidence From a Developing Nation. Evaluation Review, 30(1), 86-113. http://dx.doi: 10.1177/0193841X05276688

Seyler, D. L., Holton III, E. F., Bates, R. A., Burnett, M. F., \& Carvalho, M. A. (1998). Factors affecting motivation to transfer training. International Journal for Training and Development, 2(1), 2-16. http://dx.doi.org/10.1111/1468-2419.00031 


\section{Macrothink}

Journal of Studies in Education

ISSN 2162-6952 2016, Vol. 6, No. 4

Sife, A. S., Lwoga, E. T., \& Sanga, C. (2007). New technologies for teaching and learning: Challenges for higher learning institutions in developing countries. International Journal of Education and Development using ICT, 3(2). http://ijedict.dec.uwi.edu/viewarticle.php?id=246

Teddlie, C. \& Yu, F. (2007). Mixed Methods Sampling: A Topology With Examples. Journal of Mixed Methods Research, 1(1), 77-100. http://dx.doi.org/10.1177/2345678906292430

Totolo, A. (2011). Adoption and use of computer technology among school principals in Botswana secondary schools. The International Information \& Library Review, 43, 70-78. http://dx.doi.org/10.1080/10572317.2011.10762882

University of Botswana (2014/15). Undergraduate Academic Calendar 1014/2015. Gaborone: University of Botswana.

Unwin, T. (2005). Towards a framework for the use of ICT in teacher training in Africa. Open Learning, 20(2), 113-129. http://dx.doi.org/10.1080/02680510500094124

Windschitl, M. \& Sahl, K. (2002). Tracing Teachers' Use of Technology in a laptop Computer School: the Interplay of Teacher Beliefs, Social Dynamics, and Institutional Culture. American Educational Research Journal, 39(1), 165-205. http://dx.doi.org/10.3102/00028312039001165 